\title{
SKENARIO KEBIJAKAN PENGELOLAAN HUTAN RAKYAT BERKELANJUTAN DI KABUPATEN BOGOR
}

\author{
Policy Scenarios for Managing of Sustainability Private-Forests in Bogor Regency
}

\author{
Tatan Sukwika ${ }^{\mathrm{a}}$, Dudung Darusman ${ }^{\mathrm{b}}$, Cecep Kusmana $^{\mathrm{c}}$, Dodik Ridho Nurrochmat ${ }^{\mathrm{b}}$ \\ ${ }^{a}$ Program Studi Pengelolaan Sumber Daya Alam dan Lingkungan, Sekolah Pascasarjana Institut Pertanian Bogor, Kampus \\ IPB Baranangsiang, Bogor 16151 -tatan.swk@gmail.com \\ ${ }^{b}$ Departemen Manajemen Hutan, Fakultas Kehutanan, Institut Pertanian Bogor, Kampus IPB Dramaga Bogor 16680 \\ ${ }^{c}$ Departemen Silvikultur, Fakultas Kehutanan, Institut Pertanian Bogor, Kampus IPB Dramaga Bogor 16680
}

\begin{abstract}
This study discusses the policy scenarios on private-forest management in Bogor. The aims of this study are: determining leverage attribut on private-forest and formulating policy models, and making scenario for the development of the sustainability index of privately managed forest. This study uses multidimensional scalling (MDS) to analyze five dimensions. By using ordinal score on certain attribute, i.e. $O$ (the lowest) and 10 (the highest) of each attribute. Then, by using Rap-Pforest, we could estimate the leverage attribute of $f$ each dimension. To prepare policy models will use a prospective analysis. Final stages, to build strategic scenarios model. The analysis showed that there are two dimensions, i.e. ecology and legal and institutional, are moderately sustainable. While for the dimensions of economy, socio-culture, and accessibility and technology are less sustain. Based on five dimensions sustainability index, this study concludes that63 indicators were used and resulting 21 leverage-attributes. Qualitative model formulation for policy scenarios are: HRB = $f(E K N 3$, EKN4, SOS1, SOS3, LBG2, LBG3). Scenario II most realistic choice, this scenario has been able to increase the value of sustainability index of 46.35 (less sustainable) to 52.52 (quite sustainable). This study recommends, it is necessary to conduct the development strategy by involving all stakeholders as the most appropriate policy options to improve the sustainability of small scale privately managed forest in Bogor.
\end{abstract}

Keywords: Policy scenarios, private-forest management, prospective analysis, sustainability index.

(Diterima: 02-03-2017; Disetujui: 31-10-2017)

\section{Pendahuluan}

Dalam kurun waktu lima tahun terakhir, kondisi hutan di Kabupaten Bogor cukup memprihatinkan, bahkan menuju situasi kritis. Data Distanhut (2014) Kabupaten Bogor menunjukkan, bahwa kondisi lahan dan hutan yang kritis sekitar 31,800 hektar di wilayah Kabupaten Bogor. Dalam laporan Distanhut tersebut menyebutkan juga, bahwa kerusakan ini terjadi diakibatkan diantaranya oleh adanya alih fungsi lahan hutan, eksploitasi sumberdaya alam untuk akselerasi pertumbuhan pembangunan ekonomi, dan ada juga dikarenakan oleh perambahan masyarakat yang tergantung pada SDH setempat. Menurut beberapa hasil penelitian yang dilakukan oleh Chakravarty et al. (2012); Darusman dan Wijayanto (2007) bahwa faktor penyebab deforestasi di kawasan hutan adalah aktivitas penduduk, populasi, dan konversi lahan.

Luas total hutan rakyat di Bogor diperkirakan 16,945 ha, jauh lebih sedikit dari kawasan hutan negara yang dari 74,521 ha (Distanhut, 2014). Kondisi hutan rakyat ini secara kepentingan lingkungan mendekati hutan negara, yaitu sebagai hutan yang utuh artinya hutan rakyat bisa berfungsi mendekati hutan yang sesungguhnya (Darusman dan Wijayanto, 2007). Namun begitu, ternyata hutan rakyat di Kabupaten Bogor masih memiliki masalah-masalah krusial terutama terkait aspek ekologi, ekonomi, dan sosial yaitu seperti masalah kondisi kemiskinan di sekitar hutan, pendapatan petani hutan rakyat, rendahnya posisi tawar petani hutan rakyat, pembangunan wilayah yang kurang berkembang, dan lain sebagainya (Sukwika et al., 2016).

Salah satu indikator keberhasilan dari sebuah kebijakan pembangunan di sektor kehutanan adalah menekan tingkat kemiskinan di sekitar hutan. Oleh karena itu, kesejahteraan masyarakat desa hutan bisa diukur dengan keterpenuhan ekonomi masyarakat secara berkelanjutan di suatu kawasan hutan. Pernyataan ini dilandaskan informasi dari beberapa hasil kajian (Sunderlin, et al. 2008; Susilowati, 2007; Suyanto, et al. 2007; Nurrochmat, 2004), di mana kondisi kesejahteraan yang membaik mendorong masyarakat di sekitar hutan akan menjaga keberadaan hutannya.

Keberadaan hutan rakyat dapat memberi manfaat, baik secara ekologi maupun sosial ekonomi bagi masyarakat. Manfaat secara ekologi, antara lain perbaikan tata air Daerah Aliran Sungai (DAS), konservasi tanah dan perbaikan mutu lingkungan. Sedangkan manfaat ekonomi dan sosial berupa peningkatan pendapatan petani dari hutan rakyat dan kesejahteraan. Namun demikian, manfaatmanfaat tersebut perlu di lihat lebih jauh keterkaitannya, 
oleh karena itu, maka diperlukan aspek kelembagaan sebagai faktor pengaitnya. Pemasalahan yang dominan di hutan rakyat adalah pola pengelolaan yang masih sederhana, tenaga penyuluh yang terbatas, peran tengkulak yang kuat, dan harga pasar yang murah. Agar sistem usaha petani hutan rakyat berjalan dengan baik dan sejalan dengan arah kebijakan pembangunan Kabupaten Bogor, maka diperlukan insentif-insentif seperti perlindungan harga, dukungan regulasi, dan kemitraan usaha untuk menunjang kegiatan usaha petani hutan rakyat. Penelitian terkait sistem hutan rakyat secara parsial dengan berbagai sudut pandang dari aspek ekonomi, ekologi, dan sosial yang berbeda sudah dilakukan oleh Nurrochmat et al. (2014); Suprapto (2010); Darusman dan Wijayanto (2007).

Banyak faktor yang menyebabkan kerusakan hutan rakyat di Kabupaten Bogor, namun kerusakan ini jika ditinjau sisi pengelolaan hutan, umumnya banyak dikarenakan belum mengacu kepada aspek-aspek manajemen hutan. Sebagai contoh, penanaman kayu di hutan rakyat dapat dilakukan kapan saja meskipun tidak dilakukan penebangan, dan sebaliknya penebangan dapat dilakukan kapan saja sesuai kebutuhan (tebang butuh). Ada juga permasalahan dari sisi teknis dan kelayakan finansial. Hambatan lain dalam pengelolaan hutan rakyat yang terjadi selama ini, hampir secara umum bukan disebabkan oleh faktor teknis semata, namun lebih disebabkan oleh faktor sosial. Dan hingga saat ini, tantangan terberat dalam mengembangkan pengelolaan hutan berkelanjutan adalah masalah kemiskinan. Situasi seperti ini sudah dibuktikan pula melalui kajian-kajian yang pernah dilakukan oleh Plencovich (2014); Birgantoro \& Nurrochmat (2007). Selain kemiskinan, isu-isu lain yang berkaitan dengan hutan rakyat adalah rendahnya tingkat kepemilikan tanah, pendidikan rendah, dan kurangnya keterampilan sektor non pertanian dan kehutanan (Kant et al., 2013; Kusmana, 2011; Zhang dan Pearse, 2011).

Peran desa hutan rakyat dalam pembangunan wilayah tentunya sangat penting, karena banyak potensi yang dimilikinya. Kenyataannya, hutan rakyat yang mempunyai fungsi produksi dan konservasi justeru masih kurang mendapatkan peranan. Selama ini pengembangan hutan rakyat di Kabupaten Bogor masih bersifat parsial dan belum terintegrasi dengan perencanaan pembangunan kehutanan secara utuh dalam rangka pengembangan wilayah. Sehingga perlu sebuah formulasi model kebijakan pengelolaan keberlanjutan hutan rakyat yang dapat dipastikan bahwa rencana pembangunan kehutanan rakyat yang akan dijalankan tidak menimbulkan permasalahan baru yang lebih serius dari persoalan awal yang tidak kalah rumit seperti aspek ekologi, ekonomi, sosial, kelembagaan, dan aksesibilitas.

Berdasarkan uraian di atas, pengeloaan hutan rakyatyang terintegrasi dalam pembangunan kehutanan kabupaten secara seimbang-dapat dijadikan sebagai strategi terpenting untuk menangani masalah potensi hutan negara yang semakin menurun dan terwujudnya pengelolaan hutan rakyat yang lebih baik secara berkelanjutan. Dengan strategi ini, persoalan masalah- masalah seperti sosial, ekonomi, dan ekologi secara umum dapat diinternalisasikan dalam proses pembangunan kehutanan secara terintegrasi. Oleh karena itu, menjadi penting dilakukan kajian pengelolaan hutan rakyat berkelanjutan yang lestari yang mempertimbangkan kepada aspek-aspek keberlanjutan yaitu aspek sosial, ekologi, dan ekonomi dalam satu kesatuan unit kelestarian. Untuk mengatasi pengelolaan sumber daya hutan yang semakin mengancam pada aspek-aspek keberlanjutan tersebut, maka penelitian ini mencoba mencari salah satu arah solusinya, yaitu dengan merumuskan model kebijakan pengelolaan hutan rakyat berkelanjutan. Tujuan penelitian ini adalah (1) menganalisis kondisi status keberlanjutan pengelolaan hutan rakyat, (2) merumuskan model pengembangan keberlanjutan hutan rakyat, dan (3) menyusun skenario-skenario strategi pengembangan kebijakan keberlanjutan hutan rakyat yang memungkinkan terjadi di masa yang akan datang di Kabupaten Bogor.

\section{Metodologi Penelitian}

\subsection{Lokasi dan Waktu Penelitian}

Penelitian ini dilakukan di 18 kecamatan Kabupaten Bogor yang memiliki kawasan hutan rakyat dan tersebar di sembilan BP3K (Balai Penyuluhan Pertanian, Perikanan dan Kehutanan) berdasarkan zona wilayah dengan rincian kecamatan sebagaimana pada Tabel 1. Lokasi penelitian dapat di lihat pada Gambar 1. Penelitian dilaksanakan selama 10 bulan dimulai bulan Maret 2015.

Pengambilan sampling terdiri atas (1) Sampling Pakar. Jenis pengambilan sampel dalam penelitian ini adalah para stakeholder yang berperan sebagai key informan, baik dari unsur pakar dari pemerintah, masyarakat, dan unsur pemerhati kehuhatan rakyat di Kabupaten Bogor. Pemilihan informan dilakukan melalui teknik snowball sampling (Subagyo, 2006); dan (2) Sampling Petani Hutan Rakyat. Pengambilan sampling di tingkat petani (kelompok tani hutan rakyat/KTHR) dilakukan sebagai pelengkap informasi dan/atau klarifikasi atas hasil analisis pakar atau key informan. Metoda penentuan sampel dilakukan secara purposive pada masyarakat petani. Sample diambil secara multistage random sampling berdasarkan populasi petani hutan rakyat yang tergabung dalam kelompok tani hutan rakyat. Data yang digunakan berupa data sekunder dan data primer. Data sekunder yang digunakan tahun 2010-2015 dan data primer diperoleh dari wawancara pakar dengan menggunakan kuesioner dan panduan pertanyaan yang berkembang selama wawancara berlangsung, dirancang sesuai dengan atribut masing-masing indikator dalam skala ordinal, 0 untuk buruk dan 10 untuk baik (Pitcher et al., 2013). Indikator-indikator tersebut diperoleh dari studi pustaka CIFOR, PHPL (pengelolaan hutan produksi lestari), Permenhut, BPS (badan statistik pusat), jurnal penelitian, dan panduan standar lain serta berdasarkan pengamatan di lapangan sesuai dengan prinsip-prinsip pembangunan berkelanjutan. 


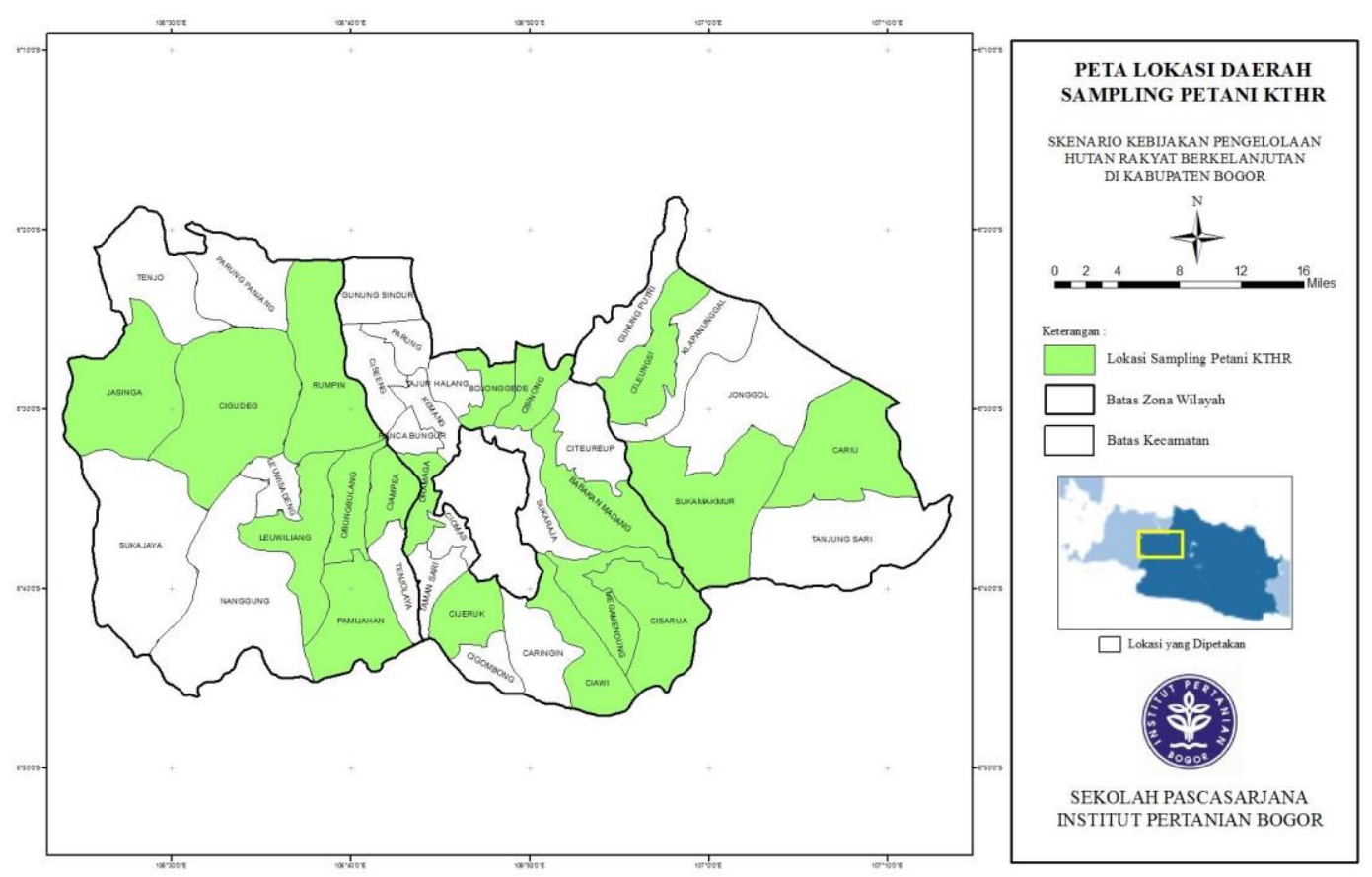

Gambar 1. Sebaran responden petani kelompok tani hutan Kabupaten Bogor

Tabel 1. Kecamatan lokasi penelitian berdasarkan BP3K dan zona wilayah

\begin{tabular}{|c|c|c|}
\hline No & BP3K (9) & Kecamatan (18) \\
\hline \multicolumn{3}{|l|}{ Zona Timur } \\
\hline 1 & Cariu & Cariu \\
\hline \multirow[t]{2}{*}{2} & Jonggol & Cileungsi \\
\hline & & Sukamakmur \\
\hline \multicolumn{3}{|l|}{ Zona Tengah } \\
\hline \multirow[t]{4}{*}{1} & Cibinong & Cibinong \\
\hline & & Babakan Madang \\
\hline & & Bojonggede \\
\hline & & Sukaraja \\
\hline \multirow[t]{2}{*}{2} & Ciawi & Cisarua \\
\hline & & Ciawi \\
\hline 3 & Caringin & Cijeruk \\
\hline 4 & Dramaga & Dramaga \\
\hline \multicolumn{3}{|l|}{ Zona Barat } \\
\hline \multirow[t]{3}{*}{1} & Cibungbulang & Cibungbulang \\
\hline & & Pamijahan \\
\hline & & Ciampea \\
\hline \multirow[t]{3}{*}{2} & Leuwiliang & Leuwiliang \\
\hline & & Rumpin \\
\hline & & Jasinga \\
\hline 3 & Cigudeg & Cigudeg \\
\hline
\end{tabular}

\subsection{Prosedur Penelitian}

Untuk mendeteksi tingkat keberlanjutan digunakan analisis Multidimensional Scaling (MDS) (Young, 2009; Borg dan Groenen, 1997). Melalui metode MDS, posisi titik keberlanjutan dapat divisualisasikan melalui sumbu horisontal dan vertikal. Dengan rotasi, posisi titik dapat divisualisasikan pada sumbu horisontal dengan nilai tingkat nilai indeks keberlanjutan. Indeks keberlanjutan adalah nilai masing-masing dimensi yang menggambarkan tingkat keberlanjutan. Nilai indeks keberlanjutan ini disajikan pada Tabel 2 (Fauzi dan Anna, 2005).

Tabel 2. Kategori penilaian berdasarkan nilai indeks status keberlanjutan

\begin{tabular}{ccc}
\hline $\begin{array}{c}\text { Nilai Indeks } \\
\text { (Persen) }\end{array}$ & Kategori & Keterangan \\
\hline $00.00-25.00$ & buruk & tidak berkelanjutan \\
$25.01-50.00$ & kurang & kurang berkelanjutan \\
$50.01-75.00$ & cukup & cukup berkelanjutan \\
$75.01-100.00$ & baik & berkelanjutan \\
\hline
\end{tabular}

Nilai indeks keberlanjutan masing-masing dimensi dapat divisualisasikan pada saat yang sama dalam bentuk diagram layang-layang. Simetris diagram layang-layang ditentukan oleh indeks keberlanjutan setiap dimensi (ekonomi, sosial dan budaya, ekologi, hukum dan kelembagaan dan infrastruktur dan teknologi). Selain itu, nilai indeks keberlanjutan setiap dimensi dapat ditampilkan pada diagram.

Setelah analisis MDS dan indeks keberlanjutan hutan rakyat diperoleh, analisis atribut pengungkit perlu dilakukan. Keunggulannya adalah untuk mengetahui atribut yang memberikan kontribusi terhadap nilai keberlanjutan sumber daya. Analisis leverage ini digunakan untuk melihat perubahan atribut dalam output analisis MDS. Pengaruh setiap atribut terlihat dalam bentuk perubahan rootmean square (RMS), terutama pada sumbu $\mathrm{x}$ untuk skala keberlanjutan sumber daya (Kavanagh dan Pitcher, 2004). Rumus RMS adalah sebagai berikut: 


$$
R M S=\sqrt{\left[\frac{\sum_{i=1}^{n}\{V f(i, 1)-V f(, 1)\}^{2}}{n}\right]}
$$

Dimana:

$\mathrm{V} f(i 1)$ : Nilai output MDS (setelah rotation dan flipping).

$\mathrm{V} f(, 1)$ : Median output MDS pada column-1.

Untuk penyusunan model kebijakan menggunakan analisis prospektif untuk mengolah atribut yang menjadi variable pengungkit hasil dari analisis leverage. Analisis ini digunakan untuk menentukan peubah-peubah dominan yang mempengaruhi sistem pengelolaan hutan rakyat yang dikaji. Analisis prospektif digunakan dalam mengkuantifikasi data kualitatif. Analsisi prospektif menghasilkan klasifikasi faktor-faktor yang berkaitan dengan suatu masalah. Faktor-faktor tersebut, dipetakan ke dalam 4 kuadran yaitu: (1) kuadran I=INPUT atau faktor penentu (driving variables), (2) kuadran II = STAKE atau faktor pengungkit (leverage variables), (3) kuadran III = OUTPUT atau faktor terikat (output variables), dan (4) kuadran IV = UNUSED atau faktor bebas (marginal variables).

Tabel 3. Pengaruh langsung antar faktor dalam pengelolaan hutan rakyat berkelanjutan

\begin{tabular}{|c|c|c|c|c|c|c|c|c|c|c|}
\hline $\begin{array}{c}\text { Dari } \downarrow \\
\text { Terhadap } \rightarrow\end{array}$ & A & $B$ & $\mathrm{c}$ & $\mathrm{D}$ & $\mathrm{E}$ & $\mathrm{F}$ & G & $\mathrm{H}$ & 1 & $\mathrm{~J}$ \\
\hline $\begin{array}{c}A \\
B\end{array}$ & & & & & & & & & & \\
\hline$\frac{C}{D}$ & & & & & & & & & & \\
\hline$\frac{E}{E}$ & & & & & & & & & & \\
\hline$G$ & & & & & & & & & & \\
\hline & & & & & & & & & & \\
\hline
\end{tabular}

Ket: A-J : Faktor penting dalam sistem

Panduan Penelitian Skor 0 Tidak ada pengaruh; 1 Berpengaruh kecil; 2 Berpengaruh sedang; 3 Berpengaruh sangat kuat.

Untuk melihat pengaruh langsung antar faktor dalam sistem, yang dilakukan pada tahap pertama analisis prospektif digunakan matriks (Hardjomidjojo, 2002) yang akan dijawab oleh pakar (Tabel 3). Untuk menentukan faktor kunci digunakan software analisis prospektif yang akan memperlihatkan tingkat pengaruh dan ketergantungan antar faktor di dalam sistem (Gambar 2: Bourgeois dan Jesus, 2004).

Tahapan akhir dari analisis prospektif adalah membangun skenario strategis model pengelolaan hutan rakyat berkelanjutan. Skenario ini merupakan kombinasi dari beberapa keadaan variabel-variabel kunci yang mungkin terjadi di masa mendatang. Dalam penelitian ini skenario dikelompokkan ke dalam tiga kluster skenario yaitu kluster skenario pesimis, skenario moderat, dan skenario optimis.

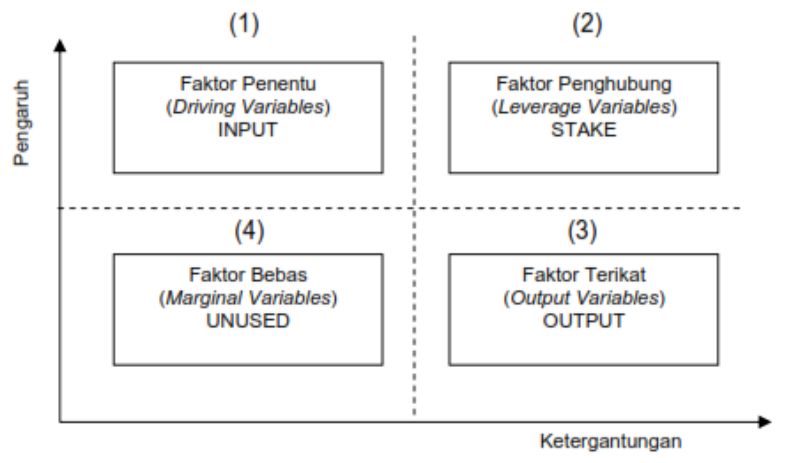

Gambar 3. Tingkat pengaruh dan ketergantungan antar faktor dalam sistem

Tabel 4. Atribut pengungkit pengelolaan hutan rakyat berkelanjutan

\begin{tabular}{|c|c|c|c|}
\hline No. & Kode & Atribut & RMS \\
\hline 1. & EKL1 & $\begin{array}{l}\text { penggunaan lahan menjadi lahan } \\
\text { terbangun }\end{array}$ & 2.33 \\
\hline 2. & EKL2 & konservasi lahan kritis & 2.20 \\
\hline 3. & EKL3 & efisiensi pemanfaatan lahan & 2.73 \\
\hline 4. & EKN1 & tenaga kerja informal & 1.57 \\
\hline 5. & EKN2 & produktivitas kayu & 2.37 \\
\hline 6. & EKN3 & pendapatan petani bulanan & 1.66 \\
\hline 7. & EKN4 & posisi tawar tengkulak & 1.71 \\
\hline 8. & EKN5 & insentif harga pasar kayu rakyat & 1.61 \\
\hline 9. & EKN6 & pasar industri kayu gergajian & 1.49 \\
\hline 10. & SOS1 & $\begin{array}{l}\text { partisipasi petani menambah nilai } \\
\text { kayu }\end{array}$ & 1.65 \\
\hline 11. & SOS2 & tingkat penyerapan tenaga kerja & 1.27 \\
\hline 12. & SOS3 & tingkat kemiskinan & 1.24 \\
\hline 13. & SOS4 & sosialisasi bertani & 1.06 \\
\hline 14. & LBG1 & lembaga keuangan mikro & 2.50 \\
\hline 15. & LBG2 & jumlah penyuluhan kehutanan & 2.59 \\
\hline 16. & LBG3 & $\begin{array}{l}\text { program penyuluhan pertanian dan } \\
\text { kehutanan }\end{array}$ & 2.67 \\
\hline 17. & LBG4 & $\begin{array}{l}\text { organisasi pemerintah bidang } \\
\text { penyuluhan }\end{array}$ & 2.32 \\
\hline 18. & ATK1 & akses jalan ke pusat layanan publik & 2.28 \\
\hline 19. & ATK2 & akses informasi pasar kayu & 2.88 \\
\hline 20. & ATK3 & pengolahan kayu pascapanen & 3.13 \\
\hline 21. & ATK4 & standar teknik penebangan & 2.24 \\
\hline
\end{tabular}

Sumber: Dimodifikasi (Sukwika, et al. 2016)

\section{Hasil dan Pembahasan}

\subsection{Status Keberlanjutan Hutan Rakyat}

Hasil analisis leverage dengan menggunakan RapPforest menunjukkan bahwa, berdasarkan 63 indikator yang diukur diperoleh 21 atribut faktor pengungkit (Tabel 4). Faktor pengungkit ditentukan dari nilai RMS atribut yang paling tinggi dibandingkan nilai atribut lainnya dalam pada setiap dimensi. Sebagai faktor pengungkit (leverage factor) maka faktor-faktor ini berperanan penting secara sensitif terhadap peningkatan atau penurunan nilai indeks keberlanjutan hutan rakyat di Kabupaten Bogor.

\subsection{Model Pengembangan Keberlanjutan Hutan Rakyat}

Hasil analisis prospektif terhadap sistem pengelolaan berkelanjutan hutan rakyat di Kabupaten Bogor disajikan pada Gambar 3. Faktor yang masuk ke dalam kuadran II merupakan faktor kunci yang memiliki karakteristik 
memiliki pengaruh dan ketergantungan terhadap sistem yang kuat sehingga dibutuhkan pengelolaan yang lebih hati-hati. Memperhatikan kemungkinan perubahan ke depan terhadap faktor dominan dalam pengelolaan hutan rakyat maka pengembangan kebijakan pengelolaan hutan rakyat berkelanjutan (HRB) merupakan hasil interaksi antara faktor (EKN3) pendapatan petani per bulan, EKN4) posisi tengkulak, (SOS1) partisipasi petani menambah nilai kayu, (SOS3) tingkat kemiskinan, (LBG2) jumlah penyuluh kehutanan, (LBG3) program penyuluhan pertanian dan kehutanan. Model kualitatif pengembangan kebijakan pengelolaan berkelanjutan hutan rakyat dapat digambarkan dalam hubungan fungsi:

$\mathrm{HRB}=\mathrm{f}(\mathrm{EKN} 3, \mathrm{EKN} 4, \mathrm{SOS} 1, \mathrm{SOS} 3, \mathrm{LBG} 2, \mathrm{LBG} 3)$

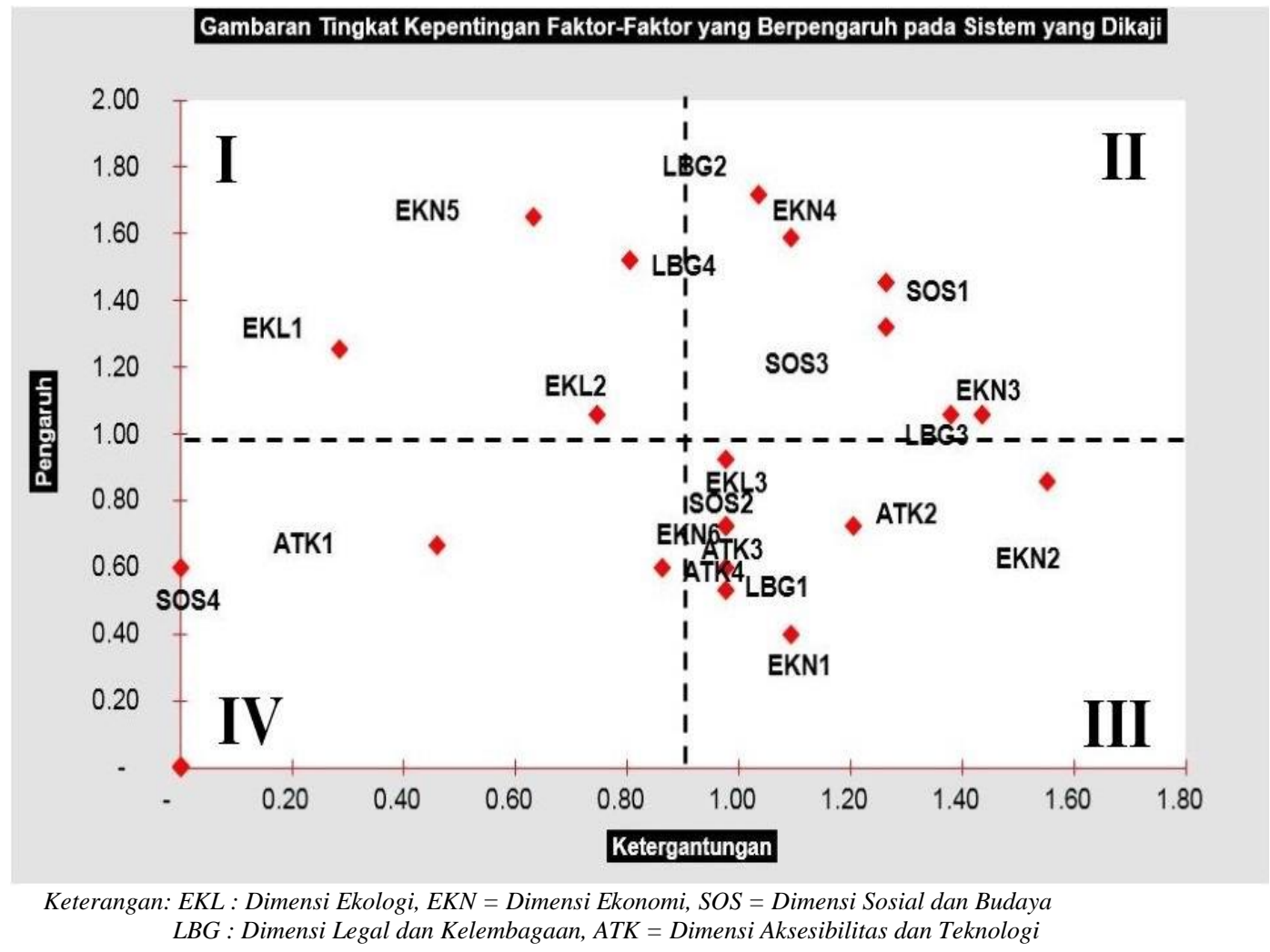

Gambar 3. Tingkat kepentingan faktor-faktor yang berpengaruh dalam sistem pengelolaan berkelanjutan hutan rakyat

\subsection{Skenario Strategi Pengembangan Kebijakan Keberlanjutan Hutan Rakyat}

Pengembangan kebijakan pengelolaan berkelanjutan hutan rakyat dilakukan berdasarkan skenario yang disusun yaitu skenario I (eksisting/pesimis), skenario II (moderat), dan skenario III (optimis) disajikan dalam Tabel 6. Seperti telah dijelaskan di atas bahwa dari 63 atribut yang dianalisis diperoleh 21 atribut yang memiliki katergori sebagai faktor pengungkit.

Selanjutnya pada tahap dilakukan analisis prospektif terhadap 21 atribut tersebur dihasilkan 6 (enam) atribut berkategori sebagai faktor kunci (key factor) yang sekaligus merupakan faktor dominan. Beberapa temuan pokok dari keenam faktor dominan tersebut yaitu, secara multidimensional, kondisi existing pengelolaan hutan rakyat menunjukkan kurang berkelanjutan. Sehingga, untuk memperoleh perubahan ke depan dalam pengelolaan hutan rakyat berkelanjutan, maka hal yang paling dimungkinkan dapat mengubah kondisi existing menjadi setingkat lebih baik atau cukup berkelanjutan adalah dengan mengintervensi kebijakan terhadap keenam faktor kunci di atas. Sebagai contoh, pada dimensi ekonomi (EKN3) nilai skoring dari pendapat pakar yaitu benilai 1, artinya, pendapatan petani per bulan dari HHBK (hasil hutan bukan kayu) di kawasan hutan rakyat di Kabupaten Bogor sangat rendah, kondisi ini jika berkepanjangan berimplikasi negatif kepada kondisi kemiskinan rumahtangga petani dan akhirnya akan mempengaruhi pola perilaku yang tidak produktif dan cenderung eksploitatif dalam mengelola lahan di hutan rakyat. Pada kondisi ini, pemerintah Kabupaten Bogor sebagai otoritas atas keberadaan hutan rakyat di wilayahnya, perlu mengajak para pihak yang berkepentingan terhadap produk hasil dari hutan rakyat. Upayanya melalui pola kemitraan yang dapat mendorong peningkatan pendapatan petani. Contoh 
temuan pokok selanjutnya, hasil skoring pada dimensi sosial (SOS3) sangat tinggi yaitu minus sembilan (-9), program pengentasan kemiskinan yang diintegrasikan ke dalam program pembangunan daerah yang difokuskan kepada pengembangan hutan rakyat terpadu di Kabupaten Bogor, dapat menekan tingkat kemiskinan rumah tangga petani. Salah satunya dengan memberikan insentif pemberdayaan petani hutan rakyat.

Nilai indeks dan status keberlanjutan pengelolaan berkelanjutan hutan rakyat hasil pengembangan kebijakan dengan skenario I, skenario II dan skenario III disajikan pada Tabel 5. Didasarkan kepada hasil analisis Rap-Pforest bahwa, kondisi existing dimensi ekologi dan dimensi aksesibilitas dan teknologi menunjukkan kondisi cukup berkelanjutan (quite sustainability), sehingga kedua dimensi tersebut tidak dilakukan simulasi di skenario II dan III. Sedangkan pada tiga dimensi yang berstatus kurang berkelanjutan (less sustainability) dilakukan simulasi. Sebagai contoh dapat dijelaskan hasil perhitungan dari Tabel 6, pada dimensi ekonomi, hasil simulasi skenario II menunjukkan perubahan indeks status keberlanjutan yaitu sebesar 52.31. Artinya, untuk bisa mengubah kondisi less sustainability menjadi quite sustainability pada dimensi ekonomi diperlukan peningkatan pendapatan petani dan pengurangan ketergantungan petahi terhadap pengaruh tengkulak. Pada skenario II (moderat) menunjukkan bahwa, keberhasilan intervensi kebijakan tehadap dua atribut tersebut dapat berimplikasi positif terhadap peningkatan nilai indeks sebesar 10.69 pada dimensi ekonomi. Sedangkan pada skenario III, meskipun terjadi peningkatan indeks keberlanjutan sebesar 60.09 atau meningkat sebasar 7.78 dari skenario II, namun peningkatan ini masih di bawah range indeks 75.01 atau masih berkategori quite sustainability (Tabel 6). Fenomena yang sama terjadi pula pada dimensi sosial dan budaya dan dimensi legal dan kelembagaan. Secara visualisisasi, nilai indeks keberlanjutan setiap dimensi berdasarkan hasil skenario I (pesimis), II (moderat), dan III (optimis) dari Tabel 7 jika di-overlay-kan akan tampak seperti disajikan pada diagram layang-layang Gambar 4.

\subsection{Pembahasan}

Ketidakberlanjutan hutan rakyat di Kabupaten Bogor di masa yang akan datang sangat ditentukan oleh kondisi existing masing-masing dimensi. Seperti telah dijelaskan dibagian sub-bab Hasil, bahwa dimensi yang kurang berlanjut pada pengelolaan hutan rakyat yaitu dimensi ekonomi, dimensi sosial-budaya, dan dimensi legal dan kelembagaan.

Pola pengelolaan hutan rakyat di Kabupaten Bogor sangat dipengaruhi oleh kondisi kemiskinan rumahtangga petani di kawasan hutan rakyat. Berdasarkan hasil observasi dan wawancara di lapangan terlihat jelas bahwa perilaku petani dalam memanfaatkan lahan hutan sangat eksploitatif dan kurang terorganisir. Secara jangka panjang, proses perilaku yang terus terjadi berulang-ulang bisa berdampak buruk pada proses keberlanjutan hutan rakyat itu sendiri. Oleh karena itu, menyikapi fenomena seperti ini, maka perlu intervensi kebijakan dari stakeholder yang dapat mengubah prilaku tersebut dalam memanfaatkan lahan hutan miliknya. Menurut Ingram et al. (2012); Guntoro (2011) perilaku tersebut dapat mengakibatkan eksternalitas negatif bagi lahan dan ekosistem sekitar kawasan hutan. Dan pada akhirnya, justru malah akan menurunkan level status keberlanjutan dari "Cukup" menjadi "Kurang". Prilaku eksploitatif terhadap lahan hutan menurut DeClerck (2006) tidak lepas dari kondisi kemiskinan petani di dekat kawasan hutan. Kemiskinan dan degradasi ekologi tidak dapat dipisahkan, degradasi ekologis menyebabkan kemiskinan, dan kemiskinan dapat meningkatkan degradasi ekologis.

Pada dimensi aksesibilitas dan teknologi, intervensi kebijakan dapat diarahkan kepada mendorong petani membiasakan memanfaatkan teknologi. Selama ini, petani sangat jarang menggunakan teknologi pemanenan kayu, meskipun mereka memiliki akses ke teknologi. Sebaliknya, pemanenan kayu sering dilakukan sepenuhnya oleh tengkulak, seperti penebangan, penyaradan, dan transportasi ke industri pengolahan kayu. Peran kuat tengkulak menurut Nurrochmat et al. (2014) memiliki dampak negatif pada kesejahteraan petani, karena berkurangnya nilai harga kayu yang diterima petani. Terkait mengurangi peran tengkulak perlu program pemerintah yang mempromosikan keterlibatan atau partisipasi masyarakat dalam sistem kebijakan hutan rakyat untuk mengembangkan manajemen berbasis kayu melalui sistem yang terintegrasi (Sahide et al., 2016; Sukwika et al., 2016). Upaya ini sejalan dengan Perpu No. 47 Tahun 1997 Pasal 45 ayat (4). 
Tabel 5. Keadaan faktor kunci dan kemungkinan perubahan ke depan dalam pengelolaan hutan rakyat berkelanjutan

\begin{tabular}{|c|c|c|c|c|}
\hline \multirow[t]{2}{*}{ No. } & \multirow{2}{*}{$\begin{array}{l}\text { Faktor Dominan/ } \\
\text { key factor }\end{array}$} & \multicolumn{3}{|c|}{ Kemungkinan Terjadi Perubahan ke Depan } \\
\hline & & A & $\mathrm{B}$ & $\mathrm{C}$ \\
\hline (1) & (2) & (3) & (4) & (5) \\
\hline \multirow[t]{3}{*}{1.} & (EKN3) pendapatan & (1) & (6) & (8) \\
\hline & $\begin{array}{l}\text { petani per bulan dari } \\
\text { HHBK }\end{array}$ & $\begin{array}{l}\text { Rendah (sedikit tersedia dan } \\
\text { tidak secara luas) }\end{array}$ & $\begin{array}{l}\text { Sedang (cukup tersedia tapi } \\
\text { tidak secara luas) }\end{array}$ & $\begin{array}{l}\text { Tinggi (ada, menopang } \\
\text { penghasilan keluarga, dan } \\
\text { cukup menguntungkan) }\end{array}$ \\
\hline & & Rendah & Meningkat, Sedang & Meningkat, Tinggi \\
\hline \multirow[t]{3}{*}{2.} & (EKN4) posisi & $(-9)$ & $(-4)$ & $(-2)$ \\
\hline & tengkulak & $\begin{array}{l}\text { Kuat (ketergantungan petani } \\
\text { pada tengkulak tinggi) }\end{array}$ & $\begin{array}{l}\text { Sedang (ketergantungan } \\
\text { petani pada tengkulak } \\
\text { berkurang) }\end{array}$ & $\begin{array}{l}\text { Sedang (ketergantungan petani } \\
\text { pada tengkulak berkurang) }\end{array}$ \\
\hline & & Kuat & Berkurang, Sedang & Berkurang, Lemah \\
\hline \multirow[t]{3}{*}{3.} & (SOS1) partisipasi & $(+1)$ & $(+6)$ & $(+9)$ \\
\hline & $\begin{array}{l}\text { petani menambah nilai } \\
\text { kayu }\end{array}$ & $\begin{array}{l}\text { Kurang (tidak tersedia } \\
\text { secara cukup) }\end{array}$ & $\begin{array}{l}\text { Sedang (cukup tersedia tapi } \\
\text { tidak secara luas) }\end{array}$ & $\begin{array}{l}\text { Sedang (cukup tersedia dan } \\
\text { secara luas) }\end{array}$ \\
\hline & & Kurang & Meningkat, Sedang & Meningkat, Tinggi \\
\hline \multirow[t]{4}{*}{4.} & (SOS3) tingkat & $(-8)$ & $(-5)$ & $(-3)$ \\
\hline & kemiskinan rumah & Tinggi (ada penopang & Menurun (ada penopang & Menurun (ada penopang \\
\hline & tangga petani & $\begin{array}{l}\text { Kesejahteraan keluarga, } \\
\text { namun kemampuan daya } \\
\text { beli sangat rendah) }\end{array}$ & $\begin{array}{l}\text { Kesejahteraan keluarga, dan } \\
\text { kemampuan daya beli rendah) }\end{array}$ & $\begin{array}{l}\text { Kesejahteraan keluarga, dan } \\
\text { kemampuan daya beli cukup) }\end{array}$ \\
\hline & & Tinggi & Menurun, Tinggi & Menurun, Sedang \\
\hline \multirow[t]{3}{*}{5.} & (LBG2) jumlah & $(+2)$ & $(+6)$ & $(+8)$ \\
\hline & penyuluh kehuta & $\begin{array}{l}\text { Tidak Ideal ketersediaan } \\
\text { tidak mencukupi) }\end{array}$ & $\begin{array}{l}\text { Mendekati ideal (tersedia tapi } \\
\text { belum cukup ideal) }\end{array}$ & $\begin{array}{l}\text { Ideal (tersedia dan mendekati } \\
\text { ideal) }\end{array}$ \\
\hline & & Tidak Ideal & Mendekati Ideal & Ideal \\
\hline \multirow[t]{3}{*}{6.} & (LBG3) program & $(+6)$ & $(+8)$ & $(+10)$ \\
\hline & $\begin{array}{l}\text { penyuluhan pertanian } \\
\text { dan kehutanan }\end{array}$ & $\begin{array}{l}\text { Cukup (tersedia tapi tidak } \\
\text { secara luas) }\end{array}$ & $\begin{array}{l}\text { Intensif (cukup tersedia tapi } \\
\text { secara luas) }\end{array}$ & $\begin{array}{l}\text { Intensif (tersedia dan secara } \\
\text { luas) }\end{array}$ \\
\hline & & Cukup Intensif & Intensif & Tetap Intensif \\
\hline
\end{tabular}

Keterangan: $A=$ kondisi eksisting skenario I (pesimis); $B=$ skenario II (moderat); $C=$ skenario III (optimis).

(0) $s / d(10)=$ nilai skoring atribut faktor dominan; +/- = Ditingkatkan/Diturunkan

Tabel 6. Nilai indeks dan status keberlanjutan hasil pengembangan kebijakan skenario I (pesimis), skenario II (moderat), dan skenario III (optimis) pengembagan hutan rakyat

\begin{tabular}{|c|c|c|c|c|c|c|c|}
\hline \multirow{2}{*}{ No. } & \multirow{2}{*}{ Dimensi } & \multicolumn{2}{|c|}{$\begin{array}{l}\text { Skenario I } \\
\text { (pesimis) }\end{array}$} & \multicolumn{2}{|c|}{$\begin{array}{l}\text { Skenario II } \\
\text { (moderat) }\end{array}$} & \multicolumn{2}{|c|}{$\begin{array}{c}\text { Skenario III } \\
\text { (optimis) }\end{array}$} \\
\hline & & $\begin{array}{c}\text { Nilai } \\
\text { Indeks }\end{array}$ & $\begin{array}{c}\text { Nilai } \\
\text { Tertimbang }\end{array}$ & $\begin{array}{c}\text { Nilai } \\
\text { Indeks }\end{array}$ & $\begin{array}{c}\text { Nilai } \\
\text { Tertimbang }\end{array}$ & $\begin{array}{c}\text { Nilai } \\
\text { Indeks }\end{array}$ & $\begin{array}{c}\text { Nilai } \\
\text { Tertimbang }\end{array}$ \\
\hline 1. & Ekologi * & 53.66 & 7.89 & 53.66 & 8.61 & 53.66 & 9.13 \\
\hline 2. & Ekonomi & 41.62 & 17.01 & 52.31 & 21.49 & 60.09 & 24.69 \\
\hline 3. & Sosial dan Budaya & 47.02 & 12.28 & 52.44 & 13.69 & 56.87 & 14.85 \\
\hline 4. & Legal dan Kelembagaan & 52.48 & 5.10 & 56.14 & 5.45 & 63.41 & 6.16 \\
\hline \multirow[t]{3}{*}{5.} & Aksesibilitas dan Teknologi $*$ & 47.56 & 3.99 & 47.56 & 4.28 & 47.56 & 4.71 \\
\hline & Nilai Indeks Keberlanjutan & 48.47 & 46.35 & 54.10 & 52.52 & 59.73 & 57.58 \\
\hline & Status & \multicolumn{2}{|r|}{$\begin{array}{c}\text { Kurang } \\
\text { Berkelanjutan }\end{array}$} & \multicolumn{2}{|r|}{$\begin{array}{c}\text { Cukup } \\
\text { Berkelanjutan }\end{array}$} & \multicolumn{2}{|r|}{$\begin{array}{c}\text { Cukup } \\
\text { Berkelanjutan }\end{array}$} \\
\hline
\end{tabular}

Keterangan: * : Tidak diperoleh faktor dominan (kunci) dari analisis prospektif.

Hasil analisis prospektif sistem pengelolaan berkelanjutan hutan rakyat di Kabupaten Bogor menunjukkan bahwa, atribut-atribut yang bisa dijadikan sebagai alat intervensi untuk mengembangkan pengelolaan hutan rakyat dalam satu kesatuan dimensi keberlanjutan adalah atribut pendapatan petani per bulan yang rendah, posisi tawar tengkulak yang cenderung dominan, partisipasi petani menambah nilai kayu yang rendah, tingkat kemiskinan yang cenderung tinggi, jumlah penyuluh kehutanan yang tidak mencukupi, dan program penyuluhan kehutanan yang kurang efektif dan optimal. Keenam atribut ini merupakan faktor kunci/dominan yang apabila dipergunakan oleh pelaku kebijakan dapat membantu perubahan ke arah yang lebih baik dalam mewujudkan perbaikan pengelolaan hutan rakyat yang lebih berkelanjutan di Kabupaten Bogor. 
JPSL Vol. 8 (2): 207-215 Agustus 2018

\section{DIAGRAM LAYANG-LAYANG}

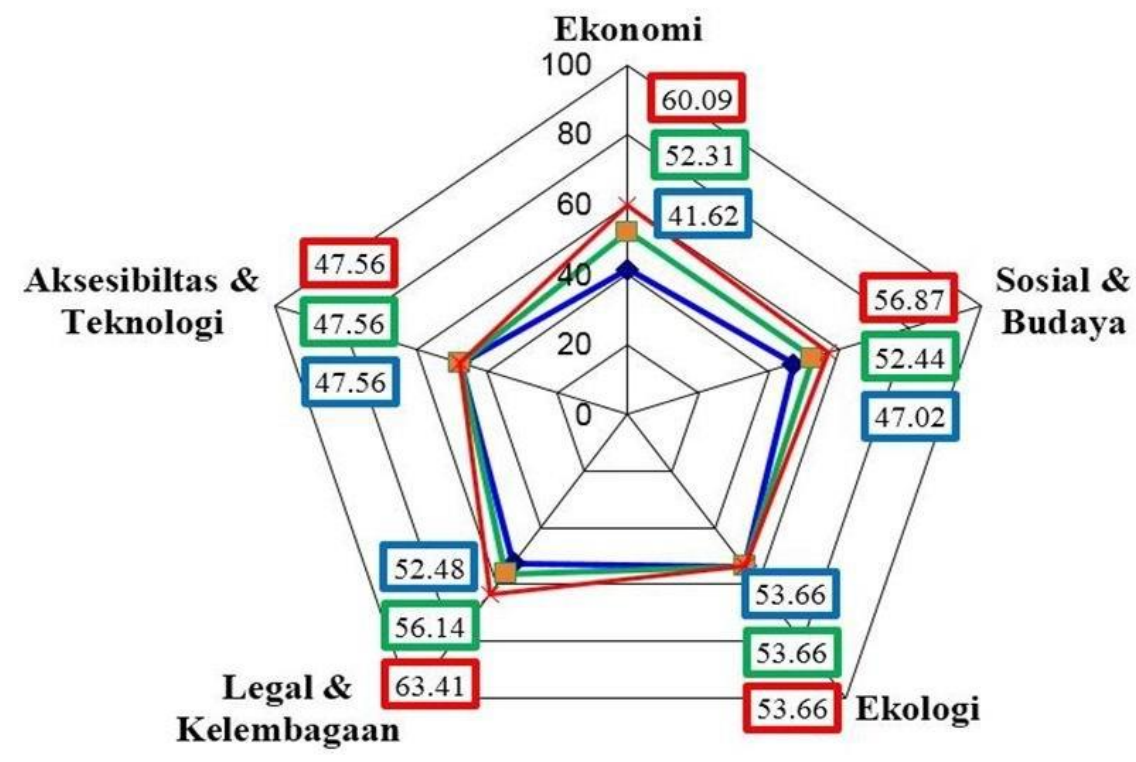

$\leadsto$ Skenario I $\rightarrow$-Skenario II $\quad \leftarrow$ Skenario III

Gambar 4. Diagram layang-layang peningkatan indeks per dimensi keberlanjutan hasil skenario pengembangan kebijakan hutan rakyat

Skenario pengembangan kebijakan pengelolaan hutan rakyat berkelanjutan yang dapat dilakukan oleh para pelaku kebijakan di Kabupaten Bogor adalah dengan mengintervensi keenam atribut tersebut sesuai kondisi yang paling memungkinan. Contohnya, kemungkinan perubahan ke depan terhadap peran dominan tengkulak dalam pengelolaan hutan rakyat berkelanjutan adalah salah satunya berupa tersedianya insentif harga kayu petani, mengintegrasikan hasil produk kayu petani ke industri pengolahan kayu, dan/atau melakukan kolaborasi membentuk smallholder. Bahkan hasil kajian Suharjito \& Purwawangsa (2014) menemukan masalah lain, di mana program pembangunan masyarakat perdesaan hanya berhenti di usaha produksi hutan saja.

Hasil observasi lapangan mengindikasikan juga bahwa terdapat dilematis petani hutan rakyat antara menjual kayu ke tengkulak atau ke industri pengergajian. Pada kenyataannya ternyata petani jarang menjatuhkan pilihaanya industri pengergajian alasannya, bila petani hutan rakyat menjual langsung ke industri penggergajian maka petani harus mengeluarkan biaya eksploitasi yang cukup tinggi. Sebaliknya jika menjual ke tengkulak, terdapat perbedaan harga yang diterima oleh petani dari tengkulak dengan industri penggergajian antara 15-30 persen. Harga kayu rendah di tingkat petani menurut Syahadat (2012) karena petani biasanya menjual kayu tersebut ke pedagang pengumpul (tengkulak) atas dasar kebutuhan dana yang mendesak meskipun umur pohon tersebut belum masak tebang (daur butuh).
Untuk memperbaiki kondisi keberlanjutan eksiting hutan rakyat, ada upaya lain yang dimungkinkan dilakukannya intervensi-intervensi kebijakan terhadap atribut-atribut kunci adalah menyusun rancangan kemungkinan perubahan ke depan dalam pengelolaan hutan rakyat berkelanjutan. Pengelolaan hutan rakyat yang berkelanjutan tidak akan pernah terwujud jika hanya berfikir untuk saat ini. Lebih jauh, pengelolaan hutan rakyat ini harus dapat diarahkan pada sektor yang dibingkai dalam model keberlanjutan dan skenario kebijakan hutan rakyat yang lebih prospektif di Kabupaten Bogor.

Model ini dapat mengarahkan pembangunan hutan rakyat yang lebih berkelanjutan dengan target pertumbuhan ekonomi wilayah secara inklusif (pro job), peningkatan kesejahteraan petani secara moderatif (pro poor), dan pembangunan hutan lestari secara intensif (pro environment). Ketiganya dapat dimanifestasikan secara holistik oleh kelima sudut dimensi aspek keberlanjutan hutan rakyat di Kabupaten Bogor.

\section{Kesimpulan}

Berdasarkan hasil penilaian terhadap 63 indikator atribut dari kelima dimensi yaitu ekologi, ekonomi, sosial dan budaya, legal dan kelembagaan, serta dimensi aksesibilitas dan teknologi konservasi maka dihasilkan 21 atribut yang menjadi faktor pengungkitnya. 
Berdasarkan hasil analisis prospektif terhadap 21 atribut pengungkit diperoleh rumusan model kualitatif yang berguna untuk pengembangan skenario kebijakan pengelolaan berkelanjutan hutan rakyat. Rumusan model kualitatif dapat digambarkan dalam hubungan fungsi : $\mathrm{KHR}=\mathrm{f}(\mathrm{EKN} 3, \mathrm{EKN} 4, \mathrm{SOS} 1, \mathrm{SOS} 3, \mathrm{LBG} 2, \mathrm{LBG} 3)$. Model kebijakan pengelolaan hutan rakyat berkelanjutan menunjukkan bahwa kebijakan pengelolaan hutan rakyat (KHR) merupakan hasil interaksi antara faktor (EKN3) pendapatan petani per bulan, (EKN4) posisi tengkulak, (SOS1) partisipasi petani menambah nilai kayu, (SOS3) tingkat kemiskinan, (LBG2) jumlah penyuluh kehutanan, (LBG3) program penyuluhan pertanian dan kehutanan.

Pengembangan kebijakan pengelolaan hutan rakyat berkelanjutan yang paling realistis dilaksanakan adalah dengan skenario II. Skenario ini telah dapat meningkatkan nilai indeks keberlanjutan dari 46.35 (kurang berkelanjutan) menjadi 52.52 (cukup berkelanjutan). Skenario II (moderat) dilakukan secara terintegratif melalui perbaikan kinerja pada atribut pengungkit pendapatan bulanan petani dari hasil hutan bukan kayu dan agroforestri menjadi setingkat lebih baik menjadi sedang, menekan kekuatan posisi tawar tengkulak menjadi sedang, meningkatkan partisipasi petani menambah nilai kayu, mengurangi tingkat kemiskinan, menambah jumlah tenaga penyuluh kehutanan yang cukup ideal, dan menjaga dan meningkatkan kualitas kegiatan program penyuluhan pertanian dan kehutanan.

\section{Daftar Pustaka}

[1] [BKP5K] Badan Ketahanan Pangan dan Pelaksana Penyuluhan Pertanian, Perikanan dan Kehutanan, 2014. Rencana Strategis Tahun 2013-2018 Badan Ketahanan Pangan dan Pelaksana Penyuluhan Pertanian, Perikanan dan Kehutanan (BKP5K). Dinas Pertanian dan Kehutanan Kabupaten Bogor, Bogor.

[2] [Distanhut] Dinas Pertanian dan Kehutanan Kabupaten Bogor, 2014. Laporan tahunan pertanian dan kehutanan. Monografi. Distanhut Kabupaten Bogor, Bogor.

[3] Birgantoro, B.A., dan D.R. Nurrochmat, 2007. Pemanfaatan sumberdaya hutan oleh masyarakat di KPH Banyuwangi Utara. Forest Resource. JMHT. 8(3), pp. 172-181. [terhubung berkala] http://repository.ipb.ac.id/handle/123456789/30961 [1 Mei 2017].

[4] Borg, I., dan P.J.F. Groenen, 1997. Modern Multidimensional Scaling: Theory and Applications. Springer, New York.

[5] Bourgeois R, dan F. Jesus, 2004. Participatory prospective analysis, exploring andanticipating challenges with stakeholders. Center for Alleviation of Poverty through Secondery Crops Development in Asia and The Pacific and French Agricultural Reasearch Center for Internasional Development Monograph. (46), pp. 1 - 29.

[6] Chakravarty, S., S.K.Ghosh, C.P. Suresh, A.N. Dey, and G. Shukla, 2012. Deforestation: causes, effects and control strategies, Global Perspectives on Sustainable Forest Management. In Clement A. Okia (Ed.), InTech Europe, Rijeka.

[7] Darusman, D., dan N. Wijayanto, 2007. Aspek ekonomi hutan rakyat (skim pendanaan). Makalah disampaikan di Pekan Hutan Rakyat II. Balai Penelitian Kehutanan, Ciamis.
[8] DeClerck, F., J.C. Ingram, and C. Rumbaitis del Rio, 2006. The role of ecological theory and practice in poverty alleviation and environmental conservation. 10, pp. 533-540.

[9] Fauzi, A., dan Z. Anna, 2005. Permodelan sumberdaya perikanan dan kelautan. Gramedia, Jakarta.

[10] Guntoro, S., 2011. Saatnya menerapkan pertanian tekno-ekologis. Sebuah model pertanian masa depan untuk menyikapi perubahan iklim. PT Agromedia Pusaka, Jakarta.

[11] Hardjomidjojo, H., 2002. Metode Analisis Prospektif. Institut Pertanian Bogor, Bogor.

[12] Ingram, J. C., K.F. DeClerc, and C. Rumbaitis del Rio (eds.), 2012. Integrating ecology and poverty reduction: the application of ecology in development solutions.

[13] Kant, S., S. Wang, P. Deegen, M. Hostettler, R. von Detten, T. Howard, et al., 2013. New frontiers of forest economics. Forest Policy and Eronomics. 35(2013), pp.1-8.

[14] Kavanagh, P., dan T.J. Pitcher, 2004. Implementing microsoft excel software for rapfish: A technique for the rapid appraisal of fisheries status. Tech. rept. 12(2). Fisheries Centre Research Reports, Vancouver.

[15] Kusmana, C., 2011. Forest resources and forestry in Indonesia. Forest Science and Technology, 7(4), pp. 155-160.

[16] Nurrochmat D.R., 2004. Poverty alleviation: concepts and experiences: focused on Indonesian cases. Ch.4. Gottingen, Cuviller Verlag.

[17] Nurrochmat, D.R., D. Darusman, dan D. Ruchjadi, 2014. Rekonstruksi sistem tenurial kehutanan. Risalah Kebijakan Pertanian dan Lingkungan. 1(1), pp. 24-29.

[18] Pitcher, T.J., M.E. Lam, C. Ainsworth, A. Martindale, K. Nakamura, R.I. Perry, et al., 2013. Improvements to Rapfish: a rapid evaluation technique for fisheries integrating ecological and human dimensions. Journal of Fish Biology. 83, pp.865-889.

[19] Plencovich, M.C., 2014. Voices From The forest: Integrating indigenous knowledge into sustainable upland farming. The Journal of Agricultural Education and Extension. 20(1), pp. 147149.

[20] Sahide, M.A.K., S. Supratman, A. Maryudi, and L. Giessen, 2016. Decentralisation Policy as Recentralisation Strategy: Forest Management Units and Community Forestry in Indonesia. International Forestry Review. 18(1):78-95.

[21] Subagyo, P.J., 2006. Metode penelitian dalam teori dan praktis. Rineka Cipta, Jakarta.

[22] Suharjito, D., dan H. Purwawangsa, 2014. Percepatan devolusi pengelolaan hutan. Risalah Kebijakan Pertanian dan Lingkungan. 1(1), pp. 12-17.

[23] Sukwika, T., D. Darusman, C. Kusmana, and D.R. Nurrochmat, 2016. Evaluating the level of sustainability of privately managed forest in Bogor, Indonesia. Biodiversitas Journal of Biological Diversity, 17(1), pp. 241-248.

[24] Sunderlin, W.D., S. Dewi, A. Puntodewo, D. Muller, A. Angelsen, M. Epprecht, 2008. Why forests are important for global poverty alleviation: A spatial explanation. Ecology and Society. 13(2), p. 24.

[25] Suprapto, E., 2010. Hutan Rakyat: Aspek Produksi, Ekologi dan Kelembagaan. Lembaga ARuPA, Yogyakarta.

[26] Susilowati, I., 2007. Evaluasi implementasi pengelolaan hutan bersama masyarakat (PHBM) di KPH Randublatung Blora. Tesis. Universitas Diponegoro, Semarang.

[27] Suyanto, S., N. Khususiya, B. Leimona, 2007. Poverty and environmental services: case study in Way Besai Watershed, Lampung Province, Indonesia. Ecology and Society. 12(2), p.13.

[28] Syahadat, E., 2012. Penatausahaan pemasaran kayu rakyat. [terhubung berkala] http://www.fordamof.org/files/penatausahaan-kayu-epi.pdf [1 Mei 2017]

[29] Young, F.Y., 2009. Multidimensional scaling (MDS). University of North Carolina, Chapel Hill.

[30] Zhang, D., and P.H. Pearse, 2011. Forest economics. UBC Press, Vancouver. 